\title{
Determination of iodine and sodium content in fermented meat products purchased in the Czech Republic- a pilot study
}

\author{
Pavla Steinhauserová ${ }^{1}$, Irena Řehůřková ${ }^{2}$, Jiří Ruprich ${ }^{1,2}$ \\ ${ }^{1}$ University of Veterinary and Pharmaceutical Sciences Brno, Faculty of Veterinary Hygiene and Ecology, \\ Department of Milk Hygiene and Technology \\ ${ }^{2}$ National Institute of Public Health - Center for Health, Nutrition and Food, Brno, Czech Republic
}

Received November 4, 2013

Accepted April 24, 2014

\begin{abstract}
Iodine deficiency is still one of acute global public health problems. The best strategy to ensure its required amount in human population is salt fortification with potassium iodate or iodide. Food industry plays an important role in supporting good health status of consumers. Using iodized salt in meat production is not mandatory in the Czech Republic. The aim of this pilot study was to evaluate a group of salty meat products - fermented meats purchased in the Czech Republic in terms of iodine and sodium content. Totally 36 samples purchased in 9 major retail chains, produced in 9 different European countries were analyzed by spectrophotometric methods. As the results show, the use of iodinated salt was obvious only among Czech producers. The application of iodinated and marine salt does not mean that those products are a good source of iodine. Consumers should be more informed about iodine and sodium content in food. They should also be more aware about the health impact of high sodium intake. This pilot study compares iodine and sodium content in this type of meat products produced in different European countries but purchased in the Czech Republic.
\end{abstract}

Iodised salt, meat products, health, food, monitoring

Iodine deficiency is an intensively solved public health problem throughout the entire world (EFSA 2006; WHO 2007). Although certain global progress in controlling iodine deficiency has been achieved since 2003, this issue is still challenging and affects almost one in three individuals globally (Benoist et al. 2008). Historically, the Czech Republic belongs to regions suffering from a lack of iodine. The soil is poor in iodine and its natural source is only certain mineral water. Since 1950s the situation was managed by implementing so called "iodine prophylaxis" based mainly on the supplementation of edible salt by stable iodine substances (Zamrazil 2007). In early 1990s, the results of epidemiological investigations done by endocrinologists and paediatricians pointed out that iodine deficiency in the Czech Republic deepened, which was probably caused by political and economic changes during society transition. The usual dietary iodine intake has been evaluated for different population groups according to age (Ruprich and Řehůřková 2007). The risk of a high intake has been described for children up to the age of 10 years, where the usual intake came mostly from food of animal origin (particularly from milk and milk products, eggs and chicken meat). Fish, bread and bakery products contribute less iodine. The usual diet of people over 65 years old is low in iodine for up to $50 \%$ of individuals. This was confirmed by the European Food Consumption Validation Project (EFCOVAL) studying the iodine intake in $24 \mathrm{~h}$ urine samples. A $16 \%$ of men and a $40 \%$ of women (45-65 years old) were bellow recommended daily doses (Řehůr̆ková et al. 2010).

The most widespread and best used strategy to ensure the required amount of iodine in the population's diet is salt fortification with potassium iodate or iodide (WHO 2007; Benoist et al. 2008). Despite its advantages (table salt is cheap and commonly consumed) 
this method also brings disadvantages: iodine instability during thermal processing and product storage (mainly for iodide), as well as health problems associated with an excessive sodium intake (Waszkowiak and Szymandera-Buszka 2008).

Iodized salt is commonly used in households and food production, where iodine concentration is determined by Czech legislation to $27 \pm 7 \mathrm{mg} / \mathrm{kg}$. The use of this fortified salt is not mandatory in the food industry (Decree No. 331/1997 Coll.). A relatively low and varying concentration of iodine can be found in marine salt, which is frequently marketed as beneficial.

Processed foods are a source of $70-75 \%$ sodium in average diet from which meat and meat products represent up to $26 \%$ (EFSA 2006). The food industry could play an important role in eradicating iodine deficiency (Ciriano et al. 2010). On the other hand, due to the risk of hypertension resulting in coronary heart disease, stroke and renal disease, restriction of sodium intake is necessary on a national as well as international level (WHO 2003; SACN 2003; EFSA 2006; He and McGregor 2007). According to Czech national individual food consumption study (SISP04) organized in 2003/2004, an estimated daily sodium intake is above $2 \mathrm{~g}$ /day for more than $95 \%$ of adult males and females. More than $50 \%$ of this sodium comes from added salt and between $10-20 \%$ is from meat and meat products (Ruprich et al. 2006). The daily sodium intake of the European population ranges between 3-5 $\mathrm{g}$ which corresponds to 8-11 $\mathrm{g}$ of salt. This exceeds the recommended daily dose set by WHO (2.0 g sodium/person/day) or EFSA (1.5 g sodium/person/day) (WHO 2003; EFSA 2006).

Fermented (dried) meats, a group of salty meat products with growing popularity among consumers, was selected for this pilot study. These special dried products are manufactured in many countries differing in the pig breed, type of feed, meat weight, and type of cut and processing conditions. These different factors give such products special composition and different nutritional aspects for human health (Fernandéz et al. 2007; Colmenero et al. 2010).

This pilot study should answer the question whether this kind of meat products, already known as a high source of sodium in the diet, could also be a considerable source of iodine. Possible differences between production countries were taken into account.

\section{Materials and Methods}

Totally 36 samples were purchased in 9 major retail chains in the Czech Republic, produced in these EU countries: Belgium $(n=1)$, Slovenia $(n=1)$, Slovak Republic $(n=1)$, Austria $(n=2)$, France $(n=2)$, Czech Republic $(n=5)$, Germany $(n=5)$, Italy $(n=9)$, and Spain $(n=10)$. Samples were transported to the National Institute of Public Health - Center for Health, Nutrition and Food in Brno, to a laboratory accredited according to the European Standard EN ISO/IEC 17025 for all needed analytical methods. Products were homogenized by Grindomix GM 300, Retsch, Germany $(120 \mathrm{~s}, 3000 \mathrm{rpm})$ at room temperature and kept in plastic boxes at $-18^{\circ} \mathrm{C}$ until sodium and iodine analyses.

The iodine determination is based on previously described methods (Ayiannidis and Voulgaropoulos 1988; Mahesh et al. 1992). Typically, $1 \mathrm{~g}$ of homogenized sample (triplicates) was mixed with $1 \mathrm{ml}$ of water, $2 \mathrm{ml}$ of $2 \mathrm{M} \mathrm{KOH}, 1 \mathrm{ml} \mathrm{10} \% \mathrm{ZnSO}_{4}$ with added $\mathrm{KClO}_{3}$ dried in the oven at $105{ }^{\circ} \mathrm{C}$ and burned out in the programmable muffle furnace at continuous temperature elevation up to $600{ }^{\circ} \mathrm{C}$ for $8 \mathrm{~h}$. White ash was mixed with water and centrifuged $(10 \mathrm{~min}, 440 \times \mathrm{g}$. The supernatant was used for spectrophotometric analysis based on the catalytic effect of iodine ions in the oxide-reductive reaction of $\mathrm{Ce}^{4+}$ and $\mathrm{As}^{3+}$ according to the Sandell-Kolthoff. The absorbance was measured on spectrometer Lambda 25 (Perkin Elmer, USA) at $430 \mathrm{~nm}$.

For sodium analysis the method of atomic emission spectrophotometry was used after sample mineralization and microwave digestion (Steinhauserova et al. 2011).

Results of analysed samples were expressed as iodine and sodium content per $1 \mathrm{~kg}$ of edible part (arithmetic mean of 3 parallel measurements and a standard deviation) (Excel, version 14.0).

\section{Results}

All measured results are shown in Tables 1 and 2 .

Totally, only 4 of the 36 analysed products declared the sodium content ( 3 from the 
Table 1. Iodine and sodium content measured in fermented meats purchased in different EU countries.

\begin{tabular}{|c|c|c|c|c|c|}
\hline Country & Sample identification & $\mathrm{Na}\left(\mathrm{g} \cdot \mathrm{kg}^{-1}\right)$ & $\pm \mathrm{SD}$ & $\mathrm{I}\left(\mu \mathrm{g} \cdot \mathrm{kg}^{-1}\right)$ & $\pm \mathrm{SD}$ \\
\hline \multirow{10}{*}{ Spain } & Iberian ham Bellota - Pata Negra I & 16.8 & 0.2 & 20.8 & 2.5 \\
\hline & Iberian ham - Pata Negra II & 20.4 & 0.2 & 25.6 & 3.6 \\
\hline & Iberian ham Recebo & 13.0 & 0.1 & 22.1 & 0.4 \\
\hline & Iberian ham Bellota & 16.2 & 0.0 & 28.3 & 1.1 \\
\hline & Jamon Serano Reserva & 15.1 & 0.0 & $<15$ & - \\
\hline & Jamon Curado Bodega & 15.1 & 0.1 & 589.8 & 6.3 \\
\hline & Dry pork ham - side & 16.4 & 0.1 & 17.0 & 0.4 \\
\hline & Dry pork ham - roast & 14.5 & 0.5 & 24.4 & 4.3 \\
\hline & Serano ham I & 14.8 & 0.0 & 22.2 & 1.2 \\
\hline & Serano ham II & 15.7 & 0.2 & 25.1 & 5.9 \\
\hline \multirow{9}{*}{ Italy } & Prosciutto Crudo I & 19.6 & 0.0 & 39.6 & 3.8 \\
\hline & Prosciutto Crudo II & 20.1 & 0.4 & 33.2 & 2.8 \\
\hline & Prosciutto di Parma & 13.6 & 0.2 & 29.4 & 1.5 \\
\hline & Prosciutto di San Daniele & 22.3 & 0.4 & 24.1 & 0.9 \\
\hline & Pancetta I & 9.0 & 0.0 & $<15$ & - \\
\hline & Pancetta II. - dried side & 12.2 & 0.0 & 50.4 & 2.8 \\
\hline & Coppa I & 13.4 & 0.0 & 21.2 & 3.2 \\
\hline & Coppa II - dried neck & 22.5 & 0.0 & 81.0 & 0.9 \\
\hline & Bresaola & 15.7 & 0.1 & 47.9 & 7.8 \\
\hline \multirow{5}{*}{ CR } & Prosciutto - neck I & 20.1 & 0.2 & 808.7 & 20.1 \\
\hline & Prosciutto - neck II & 13.2 & 0.3 & 569.7 & 47.3 \\
\hline & Prosciutto - roast I & 22.8 & 0.0 & 836.4 & 40.2 \\
\hline & Prosciutto - roast II & 11.0 & 0.2 & 577.7 & 29.5 \\
\hline & Prosciutto - side & 18.4 & 0.5 & 744.7 & 24.2 \\
\hline \multirow{5}{*}{ Germany } & Rustic ham & 18.6 & 0.2 & 1014.3 & 42.4 \\
\hline & Bauern ham & 14.2 & 0.1 & $<15$ & - \\
\hline & Dry ham & 22.2 & 0.1 & 79.4 & 2.3 \\
\hline & Westphalian ham & 18.6 & 0.1 & 891.3 & 29.9 \\
\hline & Schwarzwald ham & 13.8 & 0.2 & 84.4 & 0.2 \\
\hline \multirow{2}{*}{ France } & Savoy ham I & 15.5 & 0.0 & $<15$ & - \\
\hline & Savoy ham II & 15.7 & 0.2 & $<15$ & - \\
\hline \multirow{2}{*}{ Austria } & Tyrolian Kare ham & 12.8 & 0.1 & 29.0 & 3.7 \\
\hline & Styrian ham & 12.9 & 0.0 & 64.6 & 0.9 \\
\hline SR & Traviata - dry ham & 11.8 & 0.0 & 63.2 & 0.1 \\
\hline Slovenia & Kraski prosciutto & 15.4 & 0.5 & 49.7 & 4.3 \\
\hline Belgium & Arden ham & 22.1 & 0.4 & 53.3 & 7.5 \\
\hline
\end{tabular}

CR - Czech Republic, SR - Slovak Republic; I - iodine, Na - sodium; SD - Standard Deviation

Czech Republic, 1 from Italy). In all cases, the detected amount of sodium was lower than declared.

The mean amount of sodium measured in Spanish products, typical for this product category - Iberian and Serano hams, was $15 \mathrm{~g} \cdot \mathrm{kg}^{-1}$, except Iberian ham Pata Negra (20 g $\mathrm{kg}^{-1}$ of sodium). Products from the Czech Republic were made from neck, roast and side. Two different producers, with the same named product and from the same anatomical animal part (roast and neck) had different results in the sodium and iodine content. 
Table 2. The mean content, range and ratio of iodine and sodium content.

\begin{tabular}{|c|c|c|c|c|c|c|}
\hline \multirow{2}{*}{$\begin{array}{l}\text { Country } \\
\text { of production }\end{array}$} & \multirow[t]{2}{*}{ Samples (n) } & \multirow{2}{*}{$\begin{array}{c}\text { The range of } \\
\text { Na content } \\
\left(\mathrm{g} \cdot \mathrm{kg}^{-1}\right)\end{array}$} & \multirow{2}{*}{\multicolumn{2}{|c|}{$\begin{array}{l}\text { The range of } \\
\text { I content } \\
\left(\mu \mathrm{g} \cdot \mathrm{kg}^{-1}\right)\end{array}$}} & Mean I content & \multirow{2}{*}{$\frac{\text { Mean ratio I/Na }}{\left(\mu \mathrm{g} \cdot \mathrm{kg}^{-1}\right) /\left(\mathrm{g}^{\mathrm{kg}} \mathrm{kg}^{-1}\right)}$} \\
\hline & & & & & & \\
\hline Spain & 10 & $13.0-20.4$ & 15.8 & $<15-590$ & 86.1 & 5.4 \\
\hline Italy & 9 & $9.1-22.5$ & 16.5 & $<15-81$ & 40.9 & 2.5 \\
\hline CR & 5 & $11.0-22.8$ & 17.1 & $570-836$ & 707.0 & 41.3 \\
\hline Germany & 5 & $13.8-22.2$ & 17.5 & $<15-1014$ & 517.4 & 29.6 \\
\hline France & 2 & $15.5-15.7$ & 15.6 & $<15$ & $<15$ & 0.5 \\
\hline Austria & 2 & $12.8-12.9$ & 12.9 & $29-65$ & 46.8 & 3.6 \\
\hline SR & 1 & 11.8 & 11.8 & 63 & 63.2 & 5.4 \\
\hline Slovenia & 1 & 15.4 & 15.4 & 50 & 49.7 & 3.2 \\
\hline Belgium & 1 & 22.1 & 22.1 & 53 & 53.3 & 2.4 \\
\hline $\begin{array}{l}\text { Total } \\
\text { ( } 9 \text { countries })\end{array}$ & 36 & $9.1-22.8$ & 16.1 & $<15-1014$ & 174.7 & 10.9 \\
\hline
\end{tabular}

CR - Czech Republic, SR - Slovak Republic; I - iodine, Na - sodium

Only 2 products stated use of iodinated salt, but none declared its amount.

The mean iodine content in Spanish products was $25 \mu \mathrm{g} \cdot \mathrm{kg}^{-1}$ except Jamon Serano Reserva under the limit of quantification $<15 \mu \mathrm{g} \cdot \mathrm{kg}^{-1}$ and Jamon Curado Bodega with $590 \mu \mathrm{g} \cdot \mathrm{kg}^{-1}$.

Rustic ham produced in Germany declared the use of iodinated salt and this product had the highest iodine content $\left(1014 \mu \mathrm{g} \cdot \mathrm{kg}^{-1}\right)$ from all the analysed products.

Dried meats produced in the Czech Republic had the highest mean amount of measured iodine (mean $707 \mu \mathrm{g} \cdot \mathrm{kg}^{-1}$ ) in comparison with other analysed products. The iodine content in all samples was measured above $570 \mu \mathrm{g} \cdot \mathrm{kg}^{-1}$, with no sample under the limit of quantification as products from Italy, Spain, Germany and France. Only 3 of all analysed samples had a similar iodine content (Westphalian and Rustic ham from Germany and Jamon Curado Bodega from Spain) as products from the Czech Republic.

Belgian Arden ham declared iodinated salt, but compared to other products, the amount of iodine was very low $\left(53 \mu \mathrm{g} \cdot \mathrm{kg}^{-1}\right)$. The use of marine salt was stated on Austrian Tyrolian ham, but the amount of measured iodine was $29 \mu \mathrm{g} \cdot \mathrm{kg}^{-1}$, which was even lower than in Styrian ham without any use of marine salt $\left(65 \mu \mathrm{g} \cdot \mathrm{kg}^{-1}\right)$.

\section{Discussion}

According to the results obtained by the National Monitoring of Dietary Exposure made by the National Institute of Public Health in Brno, the main exposure source of iodine in the diet for the Czech population is milk, followed by yoghurts for all population age groups. Bakery and meat products contribute less, depending on the age group and the probable use of iodinated salt during their production (Řehůřková et al. 2010).

In this pilot study, the use of iodinated salt in production of fermented meats among Czech meat producers is obvious. The opposite situation was shown for the typical producers, Italy and Spain. This could be due to traditional production technology in Spain and Italy, as this type of production is new in the Czech Republic. The consumption of fermented meat is relatively low in the Czech Republic, on average about $2 \%$ of all meat products; with men consuming approximately $40 \%$ more than women (Ruprich et al. 2006). These products are becoming more popular and consumers expect superior quality 
as the price is higher than in other meat products. As the results show, the same type of ham can be produced with different sodium and iodine contents. Producers should take this into account and do the best for consumer's health benefits. On the other hand, consumers should be aware of the fact that use of iodinated or marine salt does not mean a good source of iodine.

From the global point of view, Czech Republic is a region with a consolidated iodine deficiency. But when pointing out its dietary sources, it is obvious that this problem must remain monitored.

\section{Acknowledgments}

This work was supported by the Internal Grant Agency of the University of Veterinary and Pharmaceutical Sciences Brno, Project IGA VFU 69/2011/FVHE; and by resources of the Institutional Support of Science and Development at the SZU-CZVP.

\section{References}

Ayiannidis K, Voulgaropoulos N 1988: Catalytic determination of iodine in biological materials. Analyst 113: $153-157$

Benoist B, McLean E, Andersson M, Rogers L 2008: Iodine deficiency in 2007: Global progress since 2003. Food Nutr B 29: 195-202

Ciriano MGI, Larequi E, Rehecho S, Calvo MI, Cavero RY, Navarro-Blasco I, Astiasarán I, Ansorena D 2010 : Selenium, iodine, $\omega-3$ PUFA and natural antioxidant from Melissa officinalis: A combination of components from healthier dry fermented sausages formulation. Meat Sci 85: 274-279

Colmenero FJ, Ventanas J, Toldrá F 2010: Nutritional composition of dry-cured ham and its role in healthy diet. Meat Sci 84: 585-593

Decree No. 331/1997 Coll., implementing § 18. a), d), (h)), i), (j)) and k) of Act No. 110/1997 Coll. on foodstuffs and tobacco products and amending and supplementing certain related laws for spices, edible salt, dehydrated products and flavourings and mustard, as subsequently amended (In Czech). Ministry of Agriculture, $31^{\text {st }}$ August 1997, pp. 6724-6745.

EFSA Panel on Dietetic Products, Nutrition, Allergies (NDA) 2006: Tolerable upper intake levels for vitamins and minerals. EFSA, February 2006. Available at: www.efsa.eu/en/ndatopics/docs/ndatolerableuil.pdf

Fernandéz M, Ordóñez JA, Cambero I, Santos I, Pin C, Hoz L 2007: Fatty acids composition of selected varieties of Spanish dry cured ham related to their nutritional implications. Food Chem 101: 107-112

He FJ, MacGregor GA 2007: Salt blood pressure and cardiovascular disease. Curr Opin Cardiol 22: 298-305

Mahesh DL, Deosthale YG, Narasinga Rao BS 1992: A sensitive kinetic assay for the determination of iodine in foodstuffs. Food Chem 43: 51-56

The National Institute of Public Health: Individual food consumption - the national study. Brno. Available at: http://www.chpr.szu.cz/spotrebapotravin.htm. Accessed September $15^{\text {th }}, 2013$

Ruprich J, Dofkova M, Rehurkova I, Slamenikova E, Resova D 2006: Individual Food Consumption - a National Study SISP04. CHFCH NIPH in Prague. Available at http://czvp.szu.cz/spotrebapotravin.htm (Accessed October $30^{\text {th }}, 2013$ )

Ruprich J, Rehưřrková I 2007: Information of the Scientific Committee for Food on: Iodine, Part I: The usual dietary intake for the population of the Czech Republic, NIPH, Brno. Available at:

http://www.chpr.szu.cz/vedvybor/dokumenty/informace/Info_2006_18_deklas_JOD\%20cast1.pdf. Accessed October $31^{\text {st }}, 2013$

Řehůřková I, Ruprich J, Dofková M 2010: Iodine and its dietary exposition for the population of the Czech Republic (In Czech). In IX. Konference u př́ležitosti dne jódu „Zásobení jódem a prevence tyreopatií se zaměřením na období těhotenství a kojení“. Praha, pp. 7-10

SACN - Scientific Advisory Committee on Nutrition 2003: Salt and Health. The Stationery Office, Norwich, $118 \mathrm{p}$.

Steinhauserová P, Řehůřková I, Ruprich J 2011: Comparison of meat products 'composition bearing/not-bearing claims marketed in the Czech Republic. Acta Vet Brno 80: 379-384

Waszkowiak K, Szymandera-Buszka K 2008: The application of wheat fibre and soy isolate impregnated with iodine salts to fortify processed meats. Meat Sci 80: $1340-1344$

WHO/FAO (World Health Organisation/Food and Agriculture Organisation) 2003: Expert Report: Diet, nutrition and prevention of chronic diseases. Report of a Joint WHO/FAO Experts Consultation, Geneva: WHO, 149 p.

WHO (World Health Organisation) 2007: Assessment of iodine deficiency disorders and monitoring their elimination - A guide for programme managers, $3^{\text {th }}$ edition. Geneva: WHO, $98 \mathrm{p}$.

Zamrazil V 2007: Prophylaxis of iodine deficiency and related problems (In Czech). Diabetologie, metabolismus, endokrinologie a výživa 1: 53-55 